\title{
Genetic diversity among red swamp crayfish (Procambarus clarkii) populations in the middle and lower reaches of the Yangtze River based on AFLP markers
}

\author{
B.F. Zhu ${ }^{1}$, Y. Huang ${ }^{2}$, Y.G. Dai ${ }^{3}$, C.W. $\mathrm{Bi}^{2}$ and C.Y. Hu${ }^{2}$ \\ ${ }^{1}$ Henry Fok School of Life Science, Shaoguan University, Shaoguan, \\ Guangdong Province, China \\ ${ }^{2}$ College of Life Science and Food Engineering, Nanchang University, \\ Nanchang, China \\ ${ }^{3}$ Fishery Technical Extension Station, Jiangxi Province, Nanchang, China \\ Corresponding author: C.Y. Hu \\ E-mail: hucy2008@163.com
}

Genet. Mol. Res. 12 (1): 791-800 (2013)

Received June 21, 2012

Accepted November 4, 2012

Published March 13, 2013

DOI http://dx.doi.org/10.4238/2013.March.13.8

\begin{abstract}
The red swamp crayfish has become one of the most important freshwater aquaculture species in China. At present, although it is widely distributed in the middle and lower reaches of the Yangze River basin, little is known about its population genetics and geographic distribution in China. We estimated the genetic diversity among 6 crayfish populations from 4 lakes (Hongze Lake, Poyang Lake, Dongting Lake, and Yue Lake) using AFLPs. A total of 129 loci were generated with 5 EcoRI-MseI primer combinations and scored as binary data in 139 individuals. These data were analyzed by cluster methods with the NTSYSpc software package. The 6 populations were separated into 3 major clusters by principal coordinate analysis and cluster analysis. Among the 6 populations, the highest gene diversity was found within the Nanjing population. Analysis of molecular variance demonstrated that most variation occurred within populations $(91.20 \%)$. The estimated
\end{abstract}


average $G_{\mathrm{ST}}$ value across all loci was 0.4186 , suggesting (very) low gene flow among the different localities. We conclude that there is high genetic differentiation among crayfish in the middle and lower reaches of the Yangze River. This information will help in the selection of highquality individuals for artificial reproduction.

Key words: Procambarus clarkii; AFLP; Genetic diversity; Yangtze River

\section{INTRODUCTION}

The conservation of genetic diversity is important for the long-term survival of any species (Reed and Frankham, 2003). The red swamp crayfish (Procambarus clarkii) has moved outside of its natural ranges through various mechanisms - both natural, such as migration; accidental, such as escape from holding facilities; or deliberate, for example, through human activities (Barbaresi and Gherardi, 2000). The red swamp crayfish is the dominant benthic invertebrate when present, and may to some extent counteract the aging or overgrowth and eutrophication of small freshwater ecosystems (Skurdal and Taugbøl, 1994). This crayfish dominates the biomass of many freshwater invertebrate communities and plays a major role in food webs and community structure (Usio and Townsend, 2004). On the contrary, it also constitute the main prey of several species of fish, birds, and mammals (Rodríguez et al., 2005). In fact, the red swamp crayfish has been found to exhibit properties of an r-selected species, including early maturity at small body size, rapid growth rate (Paglianti and Gherardi, 2004), and relatively short life span (Lindqvist and Huner, 1999). Because of its aggressiveness and predatory ability, it poses threats to native fauna (Gherardi et al., 2001; Renai and Gherardi, 2004). As a successful colonizer, crayfish may reduce biomass and species richness of macroinvertebrates, macrophytes, and periphyton, including drastic habitat changes with consequent decline of vertebrate and invertebrate taxa.

Habitat loss, overfishing, and the crayfish plague have also diminished crayfish populations throughout their distribution (Oidtmann et al., 2004). It is crucial that crayfish retain as much genetic variation as possible to enhance their chances for recovery (Doyle et al., 2001).

Molecular markers are useful tools in the assessment of genetic diversity (Powell et al., 1996). Amplified fragment length polymorphism (AFLP) (Vos et al., 1995) depends on the reliability of restriction fragment length polymorphism and the high efficiency of polymerase chain reaction (PCR) to amplify digested genome DNA segments selectively. AFLP is highly reliable for the assessment of genetic variation among and within populations (Maheswaran et al., 1997). AFLP has been widely applied to study genotyping, population differentiation, and genetic diversity in a wide variety of organisms, such as catfish (Mickett et al., 2003), tilapia (Agrestia et al., 2000), and penaeid shrimp (Wang et al., 2004).

In recent years, the red swamp crayfish has become an important commercial shrimp distributed mainly in the middle and lower reaches of Yangtze River and its tributaries. However, almost nothing is known about its population genetics and invasion routes in the river. Therefore, the objectives of this study were to 1) provide reliable information for the protection and restoration of wild resources and the selection of high-quality individuals for artificial reproduction, and 2) confirm the first introduction site of the species and understand the genetic diversity and population structure and potential avenues of dispersal. 


\section{MATERIAL AND METHODS}

\section{Sample collection}

From June 2009 to June 2010, we collected 139 crayfish using 15 baited cylindrical traps $(4 \mathrm{~m}$ long with a section of $32.5 \mathrm{~cm}, 2$ opposed access funnels with $10 \mathrm{~cm}$ in diameter, and a $0.7-\mathrm{cm}$ mesh) from 6 sites in Yangtze River tributaries to study genetic diversity and dispersal. These 6 sites include Hongze Lake (HZ) in Jiangsu Province; Poyang Lake (PYa), Ruihong Lake $\left(\mathrm{PY}^{\mathrm{b}}\right)$, and Ruichang Lake $\left(\mathrm{PY}^{\mathrm{c}}\right)$ in Jiangxi Province; Dongting Lake (DT) in Hunan Province, and Yue Lake (YL) in Hubei Province. The crayfish were preserved in absolute ethanol and stored at $-20^{\circ} \mathrm{C}$ before DNA extraction.

\section{DNA isolation and AFLP reactions}

Genomic DNA was isolated from approximately $1.5 \mathrm{~g}$ tissue using a Universal Genomic DNA Extraction Kit Ver. 3.0 (TaKaRa Biotechnology Co. Ltd., Dalian, China) according to manufacturer instructions. We used $0.5 \%$ agarose gel electrophoresis and a spectrophotometer to test the quality of the genomic DNA. AFLP was carried out as described by Vos et al. (1995), with some modifications. Briefly, $500 \mathrm{ng}$ genomic DNA from each crayfish was digested with $5 \mathrm{U}$ of each $E c o \mathrm{RI} / M s e \mathrm{I}$ endonucleases and bound to their respective adapters. After incubation for $24 \mathrm{~h}$ at $37^{\circ} \mathrm{C}$, the pre-amplification product was diluted (1:20) in ultrapure water and selectively amplified with $\mathrm{E}_{+3}$ and $\mathrm{M}_{+3}$ primers and $1.5 \mathrm{U}$ DyNazyme II DNA Polymerase. The diluted sample $(1 \mu \mathrm{L})$ was used as a template in a $20-\mu \mathrm{L}$ volume of final amplification with EcoRI/MseI plus 3 additional nucleotide primers.

PCR amplification was carried out in a PerkinElmer 9700 thermocycler, with 2 cycles of denaturation at $94^{\circ} \mathrm{C}$ for $30 \mathrm{~s}$, annealing at $65^{\circ} \mathrm{C}$ for $30 \mathrm{~s}$, and extension at $72^{\circ} \mathrm{C}$ for $1 \mathrm{~min}$, followed by 12 cycles of a touchdown phase in which the annealing temperature was lowered $1.5^{\circ} \mathrm{C}$ in every cycle followed by $25-28$ cycles of $94^{\circ} \mathrm{C}$ for $45 \mathrm{~s}, 53^{\circ} \mathrm{C}$ for $60 \mathrm{~s}$, and $72^{\circ} \mathrm{C}$ for $90 \mathrm{~s}$. A final extension was carried out at $72^{\circ} \mathrm{C}$ for $5 \mathrm{~min}$.

The products of selective amplification were separated on $6 \%$ polyacrylamide gels (acrylamide:bisacrylamide) for $3 \mathrm{~h}$ at $180 \mathrm{~V}$ and stained with $20 \%$ silver nitrate. Gels were fixed for 10 min with a mixed solution of $10 \%$ ethanol and $0.5 \%$ acetic acid and then stained for $30 \mathrm{~min}$ with $0.2 \mathrm{~g} / \mathrm{mL}$ silver nitrate solution. After being washed with distilled water, the gels were developed in $1.75 \mathrm{~g} / \mathrm{mL}$ sodium hydroxide solution with $0.4 \%$ formaldehyde until bands were noticeable. Finally, the gels were washed with distilled water and air dried.

\section{Data analysis}

A band was considered to be polymorphic if it was present in at least one genotype and absent in the others. A data matrix was generated in which each band was scored 1 if present and 0 if absent. The percentage of polymorphic loci, Nei's genetic diversity (Nei, 1978), Shannon index, average heterozygosity, and genetic distance (Nei, 1972) were calculated using POPGENE v. 1.31. Statistica 6.0 was used to test the difference in intrapopulation genetic distance and average heterozygosity between populations. A dendrogram of the 6 populations was constructed based on the unweighted pair-group method with arithmetic means (UPGMA) in POPGENE 3.2. Analysis of molecular variance was carried out via 
Arlequin v. 3.11 (Excoffier et al., 2005) to evaluate the distribution of genetic variation within and among samples as well as to estimate the $G_{\mathrm{ST}}$ (coefficient of gene differentiation) index. Principal coordinate analysis ( $\mathrm{PCoA}$ ) was used to evaluate the distribution of genetic distance in clusters with the POPGENE software. The statistical significance of the total and pairwise fixation indices was estimated by comparing the observed distribution generated by 1000 permutations. Gene flow estimates were derived using the equation $N_{\mathrm{m}}=0.25\left(1-G_{\mathrm{ST}}\right) / G_{\mathrm{ST}}$.

\section{RESULTS}

\section{AFLP and gene diversity}

Selectively amplified results of 5 primer combinations were analyzed in this study. A total of 129 bands were identified in 139 individuals, and the average was 25.8 bands for each primer combination. The average heterozygosity and percentage of polymorphic loci for each population are summarized in Table 1. Great variation in genetic diversity was observed among populations, as indicated by the average heterozygosity and percentage of polymorphic loci. The greatest percent polymorphism $(75.74 \%)$ was that of the HZ population; those in the $\mathrm{YL}(65.84 \%)$ and $\mathrm{PY}^{\mathrm{b}}(65.12 \%)$ populations were relatively lower. A $G_{\mathrm{ST}}$ analysis was performed to estimate differences among locations. The estimated $G_{\mathrm{ST}}$ value averaged over all polymorphic loci was 0.4184 , indicating a strong population structure (Table 2 ).

\begin{tabular}{lcccccc}
\multicolumn{2}{l}{ Table 1. Genetic diversity of the six population of Procambarus clarkii. } \\
\hline Population code & No. of alleles & $\begin{array}{c}\text { Effective No. } \\
\text { of alleles }\end{array}$ & $\begin{array}{c}\text { Nei's gene } \\
\text { diversity }\end{array}$ & $\begin{array}{c}\text { Shannon's information } \\
\text { index }\end{array}$ & $\begin{array}{c}\text { Percentage of } \\
\text { polymorphic loci }\end{array}$ & Sample No. \\
\hline PYa & $1.3953 \pm 0.4908$ & $1.2529 \pm 0.3562$ & $0.1471 \pm 0.1959$ & $0.2183 \pm 0.2834$ & $39.53 \%$ & 24 \\
RH (PY $)$ & $1.6512 \pm 0.4908$ & $1.3931 \pm 0.3138$ & $0.2848 \pm 0.1766$ & $0.2880 \pm 0.2565$ & $65.12 \%$ & 24 \\
RC (PYc) & $1.5349 \pm 0.5007$ & $1.2862 \pm 0.3409$ & $0.1736 \pm 0.1884$ & $0.2645 \pm 0.2737$ & $53.49 \%$ & 24 \\
HZ & $1.8574 \pm 0.5001$ & $1.4181 \pm 0.2080$ & $0.5829 \pm 0.1253$ & $0.4419 \pm 0.1926$ & $75.74 \%$ & 27 \\
YL & $1.7884 \pm 0.5018$ & $1.4091 \pm 0.3298$ & $0.3581 \pm 0.1857$ & $0.3412 \pm 0.2710$ & $65.84 \%$ & 19 \\
DT & $1.6177 \pm 0.4611$ & $1.3807 \pm 0.3496$ & $0.2290 \pm 0.1885$ & $0.2675 \pm 0.2677$ & $63.77 \%$ & 21 \\
Mean & $1.6408 \pm 0.4909$ & $1.3567 \pm 0.3168$ & $0.2959 \pm 0.1767$ & $0.3036 \pm 0.2575$ & $60.58 \%$ & 23 \\
\hline
\end{tabular}

$\mathrm{PY}^{\mathrm{a}}=$ Poyang Lake; RH $\left(\mathrm{PY}^{\mathrm{b}}\right)=$ Ruihong Lake; RC $\left(\mathrm{PY}^{\mathrm{c}}\right)=$ Ruichang Lake in Jiangxi Province; HZ = Hongze Lake in Jiangsu Province; YL = Yue Lake in Hubei Province; DT = Dongting Lake in Hunan Province.

\begin{tabular}{|c|c|c|c|c|}
\hline & Total gene diversity & $\begin{array}{c}\text { Gene diversity within } \\
\text { population }\end{array}$ & $\begin{array}{l}\text { Coefficient of gene } \\
\text { differentiation }\left(G_{\mathrm{ST}}\right)\end{array}$ & $\begin{array}{c}\text { Gene flow }\left(N_{\mathrm{m}}\right) \\
N_{\mathrm{m}}=0.5\left(1-G_{\mathrm{ST}}\right) / G_{\mathrm{ST}}\end{array}$ \\
\hline $\begin{array}{l}\text { Mean } \\
\text { Standard deviation }\end{array}$ & $\begin{array}{l}0.2797 \\
0.0299\end{array}$ & $\begin{array}{l}0.1626 \\
0.0096\end{array}$ & 0.4186 & 0.6944 \\
\hline
\end{tabular}

\section{Population structure}

The individual-based similarity trees with the highest cophenetic correlation values, and therefore the best fit between the distance matrix and corresponding tree, were produced through UPGMA cluster analysis (Figure 1). UPGMA was carried out to demonstrate graphically the genetic similarities among crayfish populations. The genetic similarity coefficient among populations ranged from a low of 0.7797 between the $\mathrm{HZ}$ and $\mathrm{PY}$ a populations to a high of 0.9067 be- 
tween the HZ and YL populations (Table 3). Nei's genetic distances for all pairwise comparisons were significantly different from zero. The genetic distance value $(0.2489)$ between the $\mathrm{HZ}$ and PY populations was the highest, whereas the value (0.0979) between the YL and HZ populations was the lowest (see Table 3). Therefore, the resulting dendrogram grouped the 6 populations (100 individuals) into 3 major clusters that consisted of 2 or more accessions (see Figure 1). The first cluster consisted of $17 \mathrm{PY}^{\mathrm{a}}$ accessions, $6 \mathrm{PY}^{\mathrm{b}}$ accessions, $1 \mathrm{HZ}$ accession, and $9 \mathrm{DT}$ accessions. The second cluster consisted of $8 \mathrm{PY}^{\mathrm{b}}$ accessions, $13 \mathrm{HZ}$ accessions, $15 \mathrm{YL}$ accessions, and 8 DT accessions. The third cluster consisted of $18 \mathrm{PY}^{\mathrm{c}}$ accessions and $1 \mathrm{PY}^{\mathrm{b}}$ accession. Interestingly, we found that crayfish from the $\mathrm{HZ}$ and $\mathrm{PY}{ }^{\mathrm{a}}$ populations, which were geographically close and connected through the Yangtze River, could be closely clustered together. Expectedly, the $P Y^{c}$ population, which was located far from the others, was clustered into a separate branch.

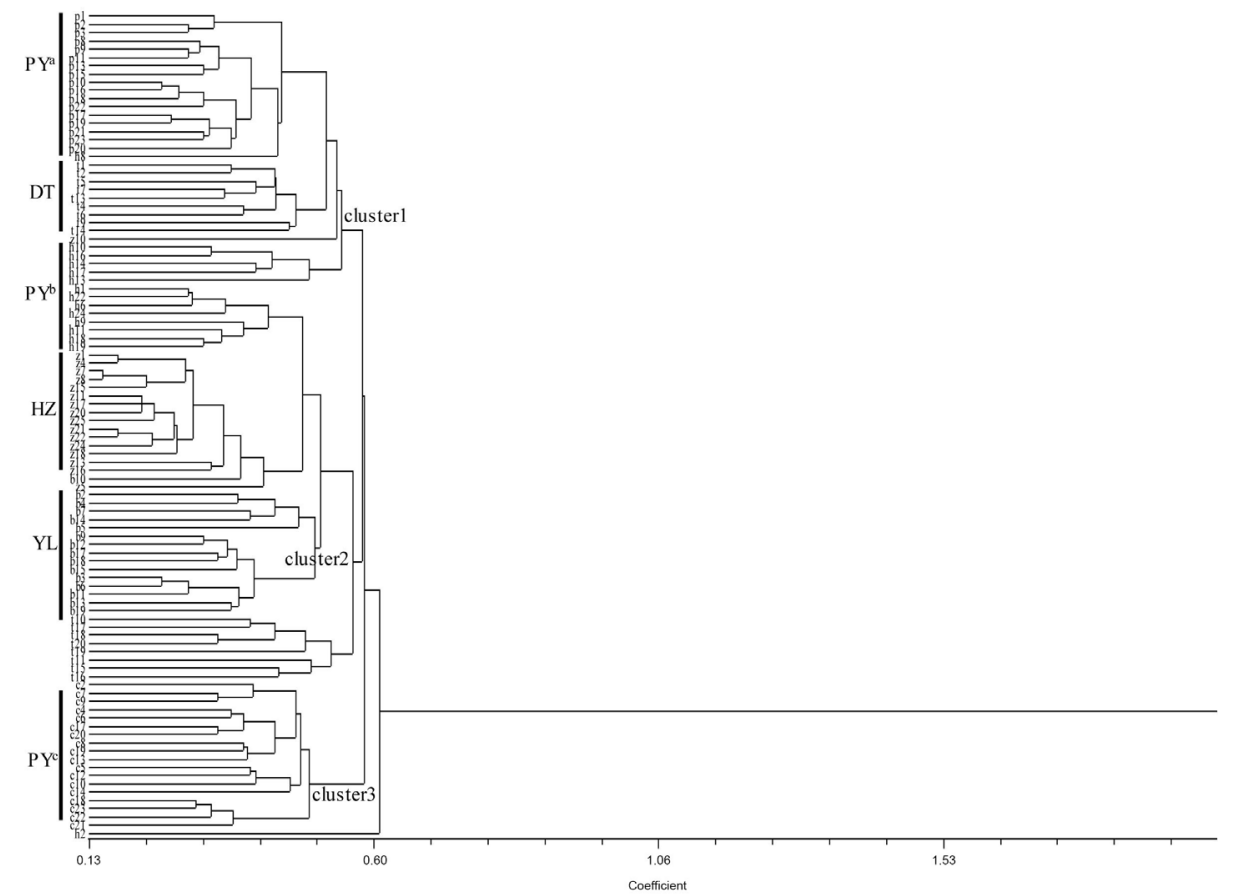

Figure 1. Principal coordinate analysis based on the distance matrix inferred from the Nei similarity index. For abbreviations, see legend to Table 1 .

Table 3. Genetic similarity indices (above the diagonal) and genetic distances (below the diagonal) among 6 populations of Procambarus clarkii.

\begin{tabular}{|c|c|c|c|c|c|c|}
\hline Population & $P Y^{\mathrm{a}}$ & $\mathrm{RH}\left(\mathrm{PY}^{\mathrm{b}}\right)$ & $\mathrm{RC}\left(\mathrm{PY}^{\mathrm{c}}\right)$ & $\mathrm{HZ}$ & YL & DT \\
\hline PYa & - & 0.8632 & 0.8062 & 0.7797 & 0.7904 & 0.8119 \\
\hline $\mathrm{RH}\left(\mathrm{PY}^{\mathrm{b}}\right)$ & 0.1474 & - & 0.8358 & 0.8745 & 0.8709 & 0.8399 \\
\hline $\mathrm{RC}\left(\mathrm{PY}^{\mathrm{c}}\right)$ & 0.2154 & 0.1793 & - & 0.8207 & 0.8505 & 0.8049 \\
\hline $\mathrm{HZ}$ & 0.2489 & 0.1341 & 0.1976 & - & 0.9067 & 0.8198 \\
\hline YL & 0.2352 & 0.1382 & 0.1620 & 0.0979 & - & 0.8743 \\
\hline DT & 0.2084 & 0.1745 & 0.2171 & 0.1987 & 0.1343 & - \\
\hline
\end{tabular}

For abbreviations, see legend to Table 1. 
Analysis of molecular variance was conducted to describe the variance components of crayfish populations. The result revealed that $91.20 \%$ of the genetic variation was explained by variation within populations and $8.80 \%$ was explained by variation among populations (Table 4).

$\begin{aligned} & \text { Table 4. Analysis of molecular variance within and among Procambarus clarkii populations with } 5 \\
& \text { microsatellites. }\end{aligned}$
\begin{tabular}{lcccrc}
\hline Source of variance & Sum of squared deviation & Variance component & Percentage of total variance & d.f. & P* \\
\hline Variance within populations & 17193.12 & 8.846 & $91.20 \%$ & 133 & $<0.001$ \\
Variance among populations & 2088.26 & 0.512 & $8.80 \%$ & 5 & $<0.001$ \\
Total & 19281.38 & 9.358 & $100.00 \%$ & 138 & \\
\hline
\end{tabular}

d.f. $=$ degrees of freedom. ${ }^{* P}$ values are the probabilities of having a more extreme variance component than the observed values alone. Probabilities were calculated by 1000 random permutations of individuals across populations.

\section{PCoA}

PCoA was also performed to display the relationship among 6 populations on 2 coordinate axes (Figure 2). Like the UPGMA clustering dendrograms, the PCoA analysis also placed 6 populations into 3 distinct groups. Up to $32.477 \%$ of the total variation was explained by the first 3 axes, which accounted, respectively, for $17.605,9.124$, and $5.748 \%$ of the observed variation. The 3 main groups from the cluster analysis appeared well separated. PYc accessions were concentrated toward the upper part of the y-axis. HZ, YL, and PYb accessions were concentrated toward the left part of the x-axis. Three ensembles overlapped widely, suggesting that hybridization among 3 populations may yield desirable genetic variability for further breeding and selection.

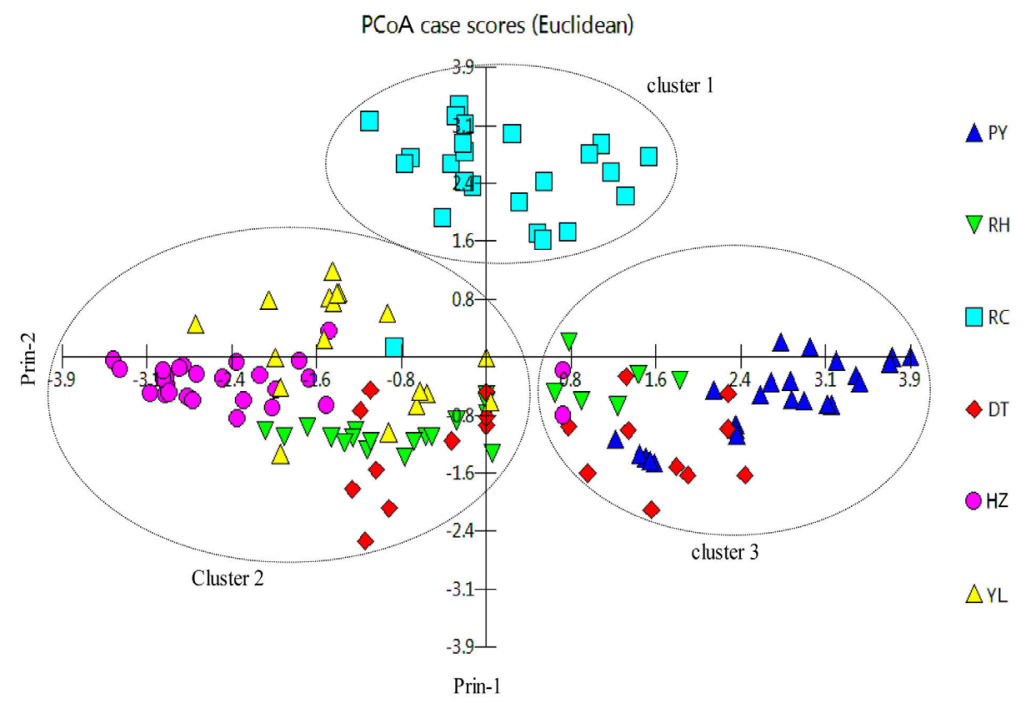

Figure 2. UPGMA dendrogram based on the Euclidean distance between the 100 sampled crayfish. PCoA = principal coordinate analysis. For population abbreviations, see legend to Table 1. 


\section{DISCUSSION}

The pattern of genetic diversity observed has practical implications for the management of broodstocks and for selective breeding programs (Song et al., 2006). Genetic diversity information among and within populations of the red swamp crayfish in the Yangtze River also provides reliable information for the protection and restoration of wild resources. Our findings clearly indicated that some distinct differences exist among the 6 populations. The $\mathrm{HZ}$ population showed the most distinct difference with the highest allelic and gene diversity. High genetic diversity of introduced populations can be attributed to several factors: multiple introductions (Kolbe et al., 2004), a single introduction of a large number of individuals from different populations (Yue et al., 2010), and remote living locations and lower fishing pressure (Song et al., 2006). Yue et al. (2010) have proved that the population in Nanjing, Jiangsu Province, may be the first invasive population of $P$. clarkii in China and that the translocation of $P$. clarkii from locations outside of China to Nanjing did not occur. The scale of introduction and fishing intensity in the $\mathrm{HZ}$ population of this species was relatively lower; which may cause high genetic diversity of introduced populations.

Successful invasive species are generally thought to have high genetic diversity, which allows them to escape the harmful effects of inbreeding and adapt to their new environment (Spielman et al., 2004). However, we found that overall gene diversity varied from 0.1471 to 0.5829 in the 6 studied crayfish populations and was lower than that of populations in the United States (0.78) (Belfiore and May, 2003). Gene diversity has clearly decreased since crayfish were introduced to China in 1929 from Japan, which may have resulted from the presence of bottleneck and founder effects and nonrandom mating (Rozas et al., 1990). Yue et al. (2010) have proved that the bottleneck effect is a crucial factor in gene diversity. Founder effects have been reported in a number of invasive species, including quagga mussel (Wilson et al., 1999), zebra mussel (Astanei et al., 2005), and Chinese mitten crab, which has invaded Europe (Herborg et al., 2007). In fact, Barbaresi et al. (2003) have shown that low genetic diversity is due to the founder effect. Because crayfish are highly fecund and can produce more than 200 eggs at each spawning (Rodríguez-Serna et al., 2000), mating between relatives is highly possible. Villanelli and Gherardi (1998) have reported that nonrandom mating and mate choice have been noted in some freshwater crayfish species. Therefore, we cannot conclude that the gene diversity within each population observed in this study was caused by a bottleneck effect and nonrandom mating.

The genetic differences among the various crayfish populations may be directly related to the distance of isolation and the connectivity level of the rivers they inhabit. The genetic distance ranged from 0.0979 to 0.2489 in our study. The genetic distance between the HZ and YL populations was the lowest, and the HZ and PYa populations had the greatest distance owing to their far distance, in which land and large rivers might have prohibited gene flow. Hedgecock et al. (1979) have reported that the population structure of freshwater crayfish is significantly influenced by several factors: land, mountains, and water level. These factors limit gene flow and therefore favor interpopulation divergence. For example, the PYa population exhibits a large seasonal water level fluctuation during the rainy season from April/ May to October (Guo et al., 2005). If water flooded and connected all marshlands and islands, the gene interchange could occur frequently for most of the populations. However, during the dry season from November to April, up to $90 \%$ of water is lost, exposing vast grass-covered 
marshlands (area: $1334 \mathrm{~km}^{2}$ ). Adult $P$. clarkii have difficulty swimming from their habitats to other sites. Therefore, water level is a crucial factor affecting the population structure of freshwater crayfish.

The $G_{\mathrm{ST}}$ value represents the degree of genetic differentiation within populations $(0<$ $G_{\mathrm{ST}}<1$ ). Mickett et al. (2003) have suggested that the $F_{\mathrm{ST}}$ (genetic differences among population) in channel catfish (0.4456) indicates a high degree of genetic differentiation, whereas Yue et al. (2004) have reported moderate genetic differentiation in Asian arowana, with a $G_{\mathrm{ST}}$ of 0.047 . In our study, $F_{\mathrm{ST}}$ averaged over all polymorphic loci was 0.4186 , which is similar to the result reported by Mickett et al. (2003). This value indicates a high degree of genetic differentiation among the 6 populations. Yue et al. (2010) have stated that genetic drift and selection may play important roles in genetic differentiation in P. clarkii. Nevertheless differences in population sizes are known to influence the degree of genetic differentiation within and between populations (Lande, 2002). Gouin et al. (2001) have maintained that human transplantation has caused genetic differentiation in the endangered freshwater crayfish. The impact of habitat variation on genetic differentiation has been illustrated in several animals, particularly crayfish (Austin and Knott, 1996). In our study, the pattern of genetic differentiation among 6 populations could be explained by 2 hypotheses. The first is based on human transplantation, which could be responsible for the differentiation. Crayfish transplantation was a common practice as early as Middle Ages, and isolated populations exist because of such activities. Thus, transplantation of crayfish from populations located in different lakes may have altered the natural genetic pattern. The second hypothesis is that this genetic pattern within and between populations can be accounted for by a period of population expansion and migration or gene flow followed by contraction, isolation, and fragmentation of populations, which leads to genetic divergence mainly under the process of genetic drift and resulted in fixation of the alternative variants in a stochastic manner. Similar patterns of genetic differentiation have been described in crayfish species using allozyme studies (Austin and Knott, 1996).

In summary, the results of genetic investigation will be useful for the development of artificial propagation and genetic improvement programs for crayfish, which give populations the ability to adapt to environmental changes and stresses. Crayfish is an extremely important economic resource in the middle and lower reaches of the Yangtze River. Furthermore, the supply of offspring from hatcheries cannot meet the demand of the market. Our research revealed that the $\mathrm{HZ}$ population has considerable genetic variety. Therefore, parental crayfish for artificial propagation should be collected from this population to ensure the conservation of wild resources and genetic diversity.

\section{ACKNOWLEDGMENTS}

Research supported by funding from the Jiangxi Provincial Bureau of Fisheries for MSC Program. The authors thank Shao Fei Guan for constructive comments.

\section{REFERENCES}

Agrestia JJ, Agrestia JJ, Agrestia JJ, Poompuang S, et al. (2000). Breeding new strains of tilapia: development of an artificial center of origin and linkage map based on AFLP and microsatellite loci. Aquaculture 185: 43-56.

Astanei I, Gosling E, Wilson J and Powell E (2005). Genetic variability and phylogeography of the invasive zebra mussel, Dreissena polymorpha (Pallas). Mol. Ecol. 14: 1655-1666. 
Austin CM and Knott B (1996). Systematics of the freswater crayfish Genus Cherax Erichson (Decapoda: Parastacidae) in south-western Australia: electrophoretic, morphological and habitat variation. Aust. J. Zool. 44: 223-258.

Barbaresi S and Gherardi F (2000). The invasion of the alien crayfish Procambarus clarkii in Europe, with particular reference to Italy. Biol. Inv. 2: 259-264.

Barbaresi S, Fani R, Gherardi F, Mengoni A, et al. (2003). Genetic variability in European populations of an invasive American crayfish: preliminary results. Biol. Inv. 5: 269-274.

Belfiore NM and May B (2003). Variable microsatellite loci in red swamp crayfish, Procambarus clarkii, and their characterization in other crayfish taxa. Mol. Ecol. 9: 2230-2234.

Doyle RW, Perez-Enriquez R, Takagi M and Taniguchi N (2001). Selective recovery of founder genetic diversity in aquacultural broodstocks and captive, endangered fish populations. Genetica 111: 291-304.

Excoffier L, Laval G and Schneider S (2005) Arlequin (version 3.0): an integrated software package for population genetics data analysis. Evol. Bioinformatics Online 1: 47-50.

Gherardi F, Renai B and Corti C (2001). Crayfish predation on tadpoles: a comparison between a native (Austropotamobius pallipes) and an alien species (Procambarus clarkii). Bull. Fr. Pêche Piscic. 361: 659-668.

Gouin N, Grandjean F, Bouchon D, Reynolds JD, et al. (2001). Population genetic structure of the endangered freshwater crayfish Austropotamobius pallipes, assessed using RAPD markers. Heredity 87: 80-87.

Guo JG, Vounatsou P, Cao CL, Utzinger J, et al. (2005). A geographic information and remote sensing based model for prediction of Oncomelania hupensis habitats in the Poyang Lake area, China. Acta Trop. 96: 213-222.

Hedgecock D, Stelmach DJ, Nelson K, Lindenfelser ME, et al. (1979). Genetic divergence and biogeography of natural populations of Macrobrachium rosenbergii. Proc. World Maricul. Soc. 10: 873-879.

Herborg LM, Weetman D, van Oosterhout C and Hanfling B (2007). Genetic population structure and contemporary dispersal patterns of a recent European invader, the Chinese mitten crab, Eriocheir sinensis. Mol. Ecol. 16: 231-242.

Kolbe JJ, Glor RE, Rodriguez SL, Lara AC, et al. (2004). Genetic variation increases during biological invasion by a Cuban lizard. Nature 431: 177-181.

Lande R (2002). Mutation and conservation. Conserv. Biol. 9: 782-791.

Lindqvist OV and Huner JV (1999). Life History Characteristics of Crayfish: What Makes Some of Them Good Colonizers? In: Crayfish in Europe as Alien Species. How to Make the Best of a Bad Situation? (Gherardi F, ed.). A.A. Balkema, Rotterdam, 23-30.

Maheswaran M, Subudhi PK, Nandi S, Xu JC, et al. (1997). Polymorphism, distribution, and segregation of AFLP markers in a doubled haploid rice population. Theor. Appl. Genet. 94: 39-45.

Mickett K, Morton C, Feng J, Li P, et al. (2003). Assessing genetic diversity of domestic populations of channel catfish (Ictalurus punctatus) in Alabama using AFLP markers. Aquaculture 228: 91-105.

Nei M (1972). Genetic distance between populations. Am. Nat. 106: 283-292.

Nei M (1978). Estimation of average heterozyosity and genetic distance from a small number of individuals. Genetics 89 : 583-590.

Nei M (1988). Genetic Distance and Molecular Phylogeny. In: Population Genetics and Fishery Management (Ryman $\mathrm{N}$ and Utter FM, eds.) Washington Sea Grant Program, Distributed by University of Washington Press, Seattle and London, 193-223.

Oidtmann B, Schaefers N, Cerenius L, Soderhall K, et al. (2004). Detection of genomic DNA of the crayfish plague fungus Aphanomyces astaci (Oomycete) in clinical samples by PCR. Vet. Microbiol. 100: 269-282.

Paglianti A and Gherardi F (2004). Combined effects of temperature and diet on growth and survival of YOY crayfish: a comparison between indigenous and invasive species. J. Crustacean Biol. 24: 140-148.

Powell W, Morgante M, Andre C, Hanafey M, et al. (1996). The comparison of RFLP, RAPD, AFLP and SSR (microsatellite) markers for germplasm analysis. Mol. Breed. 2: 225-238.

Reed DH and Frankham R (2003). Correlation between fitness and genetic diversity. Conserv. Biol. 17: 230-237.

Renai B and Gherardi F (2004). Predatory efficiency of crayfish: comparison between indigenous and non-indigenous species. Biol. Inv. 6: 89-99.

Rodríguez-Serna M, Carmona-Osalde C, Olvera-Novoa MA and Arredondo-Figuero JL (2000). Fecundity, egg development and growth of juvenile crayfish Procambarus (Austrocambarus) llamasi (Villalobos 1955) under laboratory conditions. Aquac. Res. 31: 173-179.

Rodríguez CF, Bécares E, Fernández-Aláez M and Fernández-Aláez C (2005). Loss of diversity and degradation of wetlands as a result of introducing exotic crayfish. Biol. Inv. 7: 75-85.

Rozas J, Hernandez M, Cabrera VM and Prevosti A (1990). Colonization of America by Drosophila subobscura: effect of the founder event on the mitochondrial DNA polymorphism. Mol. Biol. Evol. 7: 103-109.

Skurdal J and Taugbøl T (1994). Do we need harvest regulations for European crayfish? Rev. Fish Biol. Fish. 4: 461-485. Song J, Song ZB, Yue BS and Zheng WJ (2006). Assessing genetic diversity of wild populations of Prenant's schizothoracin, 
Schizothorax prenanti, using AFLP Markers. Environm. Biol. Fish. 77: 79-86.

Spielman D, Brook BW and Frankham R (2004). Most species are not driven to extinction before genetic factors impact them. Proc. Nat. Acad. Sci. U. S. A. 101: 15261-15264.

Usio N and Townsend CR (2004). Roles of crayfish: consequences of predation and bioturbation for stream invertebrates. Ecology 85: 807-822.

Villanelli F and Gherardi F (1998). Breeding in the crayfish, Austropotamobius pallipes: mating patterns, mate choice and intermale competition. Freshwater Biol. 40: 305-315.

Vos P, Hogers R, Bleeker M, Reijans M, et al. (1995). AFLP: a new technique for DNA fingerprinting. Nucleic Acids Res. 23: 4407-4414.

Wang ZY, Tsoi KH and Chu KH (2004). Applications of AFLP technology in genetic and phylogenetic analysis of penaeid shrimp. Biochem. Syst. Ecol. 32: 399-407.

Wilson AB, Naish KA and Boulding EG (1999). Multiple dispersal strategies of the invasive quagga mussel (Dreissena bugensis) as revealed by microsatellite analyses. Can. J. Fish. Aquat. Sci. 56: 2248-2261.

Yue GH, Li Y, Lim LC and Orban L (2004). Monitoring the genetic diversity of three Asian arowana (Scleropages formosus) captive stocks using AFLP and microsatellites. Aquaculture 237: 89-102.

Yue GH, Li J, Bai ZY, Wang CM, et al. (2010). Genetic diversity and population structure of the invasive alien red swamp crayfish. Biol. Inv. 12: 2697-2706. 